\title{
Effect of transient early hyperthyroidism on onset of puberty in Suffolk ram lambs
}

\author{
A. H. Fallah-Rad ${ }^{1}$, M. L. Connor ${ }^{1 *}$ and R. P. Del Vecchio ${ }^{2 \dagger}$ \\ ${ }^{1}$ Faculty of Agricultural and Food Sciences, University of Manitoba, Winnipeg, MB, \\ R3T 2N2, Canada; and ${ }^{2}$ Agriculture and Agri-Food Canada, Brandon Research Center, \\ Box 1000A, RR No. 3, Brandon Manitoba, R7A 5Y3, Canada
}

The thyroid function and sexual development of eight 6week-old Suffolk ram lambs were studied. The lambs were divided into either control or treatment groups and housed indoors. From 6 to 12 weeks of age, four lambs in the treatment group received $15 \mathrm{mg} \mathrm{kg}^{-1}$ body weight per day of 6-propyl 2-thiouracil orally to suppress normal thyroid function. During the same period, thyroxine and triiodothyronine were injected s.c. at the rate of 8 and $16 \mu \mathrm{g} \mathrm{kg}^{-1}$ body weight per day, respectively, to induce a hyperthyroid state. Four control lambs received sham injection and oral excipient. Concentrations of thyroxine, tri-iodothyronine, FSH, testosterone and insulin-like growth factor I were determined in blood collected by indwelling jugular catheters once a week, every $20 \mathrm{~min}$ from 09:00 to 15:20 h. Scrotal circumference was recorded each week. Semen collection was attempted by electro-ejaculation between weeks 17 and 36 . Lambs were castrated at week 36 and testicular histology was examined. During the treatment period only, the concentration of thyroid hormones was higher in treated lambs than in controls $(P<0.05)$. From week 6 to week 9 only, concentrations of FSH in treated lambs were lower than in controls $(P<0.05)$. Insulin-like growth factor I concentrations were lower in treated lambs than in controls from week 10 to week $13(P<0.05)$. Frequency of testosterone pulses was higher $(P<0.01)$ in the treated lambs but concentrations were similar in the control and treated lambs throughout the experiment. Scrotal circumference was greater in treated lambs from week 26 to week $36(P<0.05)$. Treated lambs produced viable spermatozoa earlier than did control lambs. At week 36 , sperm concentration in treated lambs was higher than in controls $(P<0.01)$ but semen volumes were similar $(P>0.1)$. Diameter of the seminiferous tubules in treated lambs was larger than in controls $(P<0.05)$. In conclusion, transient neonatal hyperthyroidism decreased $\mathrm{FSH}$ and insulin-like growth factor I concentrations temporarily, increased testosterone pulses and sperm production and advanced puberty in Suffolk ram lambs.

\section{Introduction}

Thyroid hormones can affect testis functions directly and indirectly (Palmero et al., 1988), but these effects are highly dependent upon the age of the animal (Meisami et al., 1994). Testes of adult animals have been considered unresponsive to thyroid hormones (Oppenheimer et al., 1974). However, recent evidence supports the concept of a critical role for thyroid hormones in testicular development during the perinatal period. High tri-iodothyronine $\left(T_{3}\right)$ concentrations in immature rats reduced the postnatal period of Sertoli cell proliferation and the final testicular size (van Haaster et al., 1993). Conversely, 6-propyl 2thiouracil (PTU), a potent reversible goitrogen, induced transient neonatal hypothyroidism and resulted in increased adult testis size and sperm production in rats (Cooke and

\footnotetext{
*Correspondence.

Email:mconnor@cc.umanitoba.ca

†Present address: 239 Knapp Hall, Louisiana State University, PO Box 25100, Baton Rouge, LA 70897-5100, USA
}

Meisami, 1991), hamsters (Kirby et al., 1993) and mice (Joyce et al., 1993). PTU treatment in rats decreased thyroxine $\left(T_{4}\right)$ concentration throughout the treatment period but suppressed $\mathrm{T}_{3}$ to a lesser degree (Kirby et al., 1992). Serum FSH and LH concentrations were reduced significantly in hypothyroid rats without affecting testosterone concentration.

Sertoli cells are the major determinant of the magnitude of sperm production (Orth et al., 1988). Neonatal Sertoli cell proliferation was extended up to 15 days in PTU-treated rats (van Haaster et al., 1992) and mice (Joyce et al., 1993), leading to large increases in their numbers in adults (Hess et al., 1993). However, transient neonatal hyperthyroidism decreased the proliferation rate but enhanced the differentiation of Sertoli cells (van Haaster et al., 1993). Similarly, Palmero et al. (1992) found that excess $T_{3}$ inhibited DNA synthesis and presumably proliferation in the rat prepubertal Sertoli cell culture. Immediately after cessation of PTU treatment in hypothyroid rats, the testes appeared to be immature and the lumen formation was delayed or absent. Conversely, $\mathrm{T}_{3}$ treatment accelerated the formation 
of a tubular lumen (van Haaster et al., 1993), which reflected the fluid secretion by the differentiated Sertoli cells (Russell et al., 1989). Cooke et al. (1994a) stated that the early suppression of Sertoli cell proliferation, the reduced number of these cells in adults, and the enhanced onset of Sertoli cell secretory activity in hyperthyroid young rats were all due to direct actions of thyroid hormones on the Sertoli cells.

The aim of the present study was to apply transient early hyperthyroidism in sheep to further understanding of the role of thyroid hormones and testicular development in peripubertal rams. Major differences in the rate of Sertoli cell proliferation of neonatal rats and sheep (Gondos and Berndston, 1993) make it of interest to document the effects of early hyperthyroidism on the ovine testis. In contrast to the case in rats (Dubois and Dussault, 1977), the sheep hypothalamic-pituitary-thyroid axis is well developed at the time of birth (Brzezinska-Slebodzinska and Krysin, 1990). Therefore, the potential differences between rodents and sheep in the application of transient early hyperthyroidism require investigation.

\section{Materials and Methods}

\section{Animals, housing and environment}

Eight Suffolk ram lambs were selected from a large flock after spring weaning (at $40 \pm 2$ days of age and weighing $14.4 \pm 0.6 \mathrm{~kg}$; mean $\pm \mathrm{SEM})$. Lambs were assigned randomly to either a control $(n=4)$ or PTU $+\mathrm{H}(n=4)$ group. Each group was housed in a $180 \mathrm{~cm} \times 300 \mathrm{~cm}$ pen on a concrete floor covered by wood shavings. Room light duration was adjusted each week to correspond to the natural photoperiod. Lambs had free access to fresh water and were fed ad libitum a ration of chopped hay and barleybased concentrate formulated to meet 1985 National Research Council requirements for fast growing lambs. They were maintained in accordance with the Canadian Council on Animal Care Guidelines (1993).

\section{Treatments}

PTU (Sigma-Aldrich Canada Ltd, Oakville, Ontario) was administered to the $\mathrm{PTU}+\mathrm{H}$ lambs at a rate of $15 \mathrm{mg} \mathrm{kg}^{-1}$ body weight per day from 6 to 12 weeks of age to suppress normal thyroid function. The daily dose of $0.1 \%(\mathrm{w} / \mathrm{v})$ PTU was administered by drench in two equal parts at 08:00 and 16:00 h. PTU also suppresses hepatic and peripheral $\mathrm{T}_{3}$ production. Therefore, PTU $+\mathrm{H}$ lambs were also given daily s.c. injections of $8 \mu \mathrm{g} \mathrm{T}$ and $16 \mu \mathrm{g} \mathrm{T}_{4} \mathrm{~kg}^{-1}$ body weight (Sigma Chemical Co., St Louis, MO) to induce a hyperthyroid state during the treatment period. $\mathrm{T}_{3}$ and $\mathrm{T}_{4}$ solutions were prepared by dissolving both hormones in alkalinized saline as described by Lynch et al. (1983) with some modifications as follows: $2500 \mu \mathrm{g} \mathrm{T}$ and $1250 \mu \mathrm{g} \mathrm{T}_{3}$ were dissolved in a mixture of $5 \mu \mathrm{l}$ of $1 \mathrm{~mol} \mathrm{NaOH} \mathrm{I}^{-1}$ and $495 \mu \mathrm{l}$ of $95 \%$ ethanol, and vortexed. This solution was mixed with a solution comprising $2.5 \mathrm{ml}$ propylene glycol and $7 \mathrm{ml}$ normal saline. The final solution had approximately $250 \mu \mathrm{g} \mathrm{T}_{4}$ and $125 \mu \mathrm{g} \mathrm{\textrm {T } _ { 3 }} \mathrm{ml}^{-1}$. The control lambs were given placebo and injected s.c. with normal saline.

\section{Blood sampling}

Blood was collected from lambs each week between 6 and 36 weeks of age, every 20 min from 09:00 to 15:20 h, by indwelling jugular catheters put in place according to the procedure of Sakurai et al. (1993).

Haematocrits were determined every $2 \mathrm{~h}$ during the sampling day. Blood samples were stored for up to $16 \mathrm{~h}$ at $4^{\circ} \mathrm{C}$. Serum was collected after centrifugation for $20 \mathrm{~min}$ at $2000 \mathrm{~g}$ and stored at $-20^{\circ} \mathrm{C}$ until assayed for concentrations of $\mathrm{T}_{4}, \mathrm{~T}_{3}, \mathrm{FSH}$, testosterone and insulin-like growth factor I (IGF-I).

\section{Growth measurements}

Scrotal circumference of the lambs was measured each week from 6 to 36 weeks of age with a cloth measuring tape while the lambs were restrained in a sitting position. Scrotal wool was clipped off and the testes were pulled fully into the scrotum before measurement. Body weight, average daily gain, relative growth (increase in body weight as a percentage of the total body weight) and average daily feed intake were measured and calculated each week until 36 weeks of age.

\section{Semen collection and evaluation}

Attempts to collect semen were made twice a week from week 17 to week 36 by electro-ejaculation and semen samples were evaluated immediately. The sperm concentration was determined from a $20 \mu \mathrm{l}$ sample of the ejaculate fixed in acetic acid. The number of sperm cells was counted using a haemocytometer (Reichert Scientific Instruments, Buffalo, NY). The volume of the semen was recorded and the percentage of non-motile spermatozoa was calculated.

\section{Testicular histology}

Rams were castrated surgically at 36 weeks of age after their scrotal circumference had reached a plateau and at a time corresponding to the late breeding season. Testes were weighed and histological sections prepared by the haematoxylin and eosin staining method to examine the number, diameter and number of layers of cells in the seminiferous tubules. Diameter of seminiferous tubules was determined with the aid of a calibrated microscopic slide. Number of layers of cells was determined by counting the average number of cells standing in a column from the periphery to the lumen of seminiferous tubules in four different directions. Owing to the large diameter of the testes, it was not possible to count the total number of seminiferous tubules in the cross-section of the testis and therefore the number of seminiferous tubules per view field of the microscope was counted at a magnification of $\times 100$. 
At least ten fields of view were observed to obtain the average number and diameter of seminiferous tubules. Longitudinal sections were avoided as much as possible.

\section{Hormone concentrations and pulse calculations}

Mean hormone values for each sheep were calculated from the 19 samples taken at 20 min intervals on sampling days for testosterone and from samples taken hourly for $\mathrm{T}_{4}$, $\mathrm{T}_{3}, \mathrm{FSH}$ and IGF-I. Pulses of testosterone were calculated according to the method described by Veldhuis et al. (1984), which is based on the measurements of the hormone that exceed the preceding local minimum by a value that is fourfold greater than the intra-assay coefficient of variation $(\mathrm{CV})$ of the radioimmunoassay. This method allows elimination of the noises produced by the error of the assay and produces fewer false positive pulses compared with other methods. The ratio of $\mathrm{T}_{4}: \mathrm{T}_{3}$ during and after treatment period was calculated.

\section{Testosterone radioimmunoassay}

Concentrations of testosterone were determined in duplicate by radioimmunoassay using the procedure described by Sanford et al. (1974). The mean intra-assay CVs for high, medium and low reference pools of serum were calculated according to the procedure of Wilson and Lapwood (1979) and were 13.1, 12.2 and 12.9\%, respectively, whereas the mean interassay $\mathrm{CV}$ was $14.2 \%$. The concentrations of testosterone were expressed as $\mathrm{ng} \mathrm{ml}^{-1}$.

\section{Thyroxine and tri-iodothyronine radioimmunoassays}

Total $T_{4}$ and $T_{3}$ assays were performed by radioimmunoassay using Coat-A-Count ${ }^{\circledR}$ kits (total $\mathrm{T}_{4} 11081$ and total $T_{3} 1501$ for $T_{4}$ and $T_{3}$, respectively; Diagnostic Products Corp. Los Angeles, CA). Similar procedures have been used by others (Milter and Albyl, 1985; Wrutniak et al., 1985) in sheep. Mean $\mathrm{T}_{4}$ and $\mathrm{T}_{3}$ intra-assay $\mathrm{CV}$ s were 3.9 and $6.3 \%$, respectively, whereas inter-assay $C V$ s were $7.3 \%$ for $\mathrm{T}_{4}$ and $14.95 \%$ for $\mathrm{T}_{3}$. The values of $\mathrm{T}_{4}$ and $\mathrm{T}_{3}$ are expressed as $\mu \mathrm{g}$ and $\mathrm{ng} \mathrm{dl}-1$, respectively. Sensitivity of the

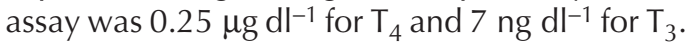

\section{ELISA for insulin-like growth factor I}

IGF-I concentrations were determined using IGF-I ELISA kits (Diagnostic Systems Laboratories, Inc., Webster, TX). This method involves acid ethanol extraction, which has been confirmed to be the most reliable method of extraction (Breier et al., 1986; Daughaday et al., 1989). Similarity of purified ovine IGF-I to human IGF-I in structure and biological activity has been demonstrated (Breier et al., 1986; Francis et al., 1989). The amino acid sequence of ovine IGF-I is identical to that of human IGF-I except for amino acid number 66 (Francis et al., 1989).

The mean intra-assay CV for IGF-I was $3.2 \%$ and the inter-assay CV was 5.6\%. The values of IGF-I are expressed as $\mathrm{ng} \mathrm{ml}^{-1}$. The sensitivity of the assay was $0.03 \mathrm{ng} \mathrm{ml}^{-1}$.

\section{FSH radioimmunoassay}

Serum samples were assayed for FSH according to the method described by Evans et al. (1992). The average intraand inter-assay CVs were $3.1 \%$ and $7.8 \%$, respectively. Sensitivity of the assay was $0.1 \mathrm{ng} \mathrm{ml}^{-1}$.

\section{Statistical analysis}

The design of the experiment was a completely randomized design (CRD) with repeated measures over time for hormone values. All the data are shown as mean \pm SEM unless stated otherwise. Statistical analysis used ANOVA and Student's $t$ test, where appropriate. For measurements that were taken once a week, the analysis was a CRD. For measurements taken repeatedly within a week, the analysis was a CRD with repeated measures. For the repeated measures procedure, animal within treatment was used as the error term to test treatment, whereas time and treatment $\times$ time effects were tested using animal within treatment $\times$ time as the error term. If significant treatment or treatment interaction effects were found, they were further investigated using the LSD test (Steel and Torrie, 1960), holding experimental error at 0.05. Haematocrit measurements from 09:00 and 15:20 h were analysed using a paired $t$ test assuming equal variances. Correlation coefficients ( $r$ values) were calculated and if the absolute value was more than 0.5 , it was considered a significant correlation. Owing to changes in the concentration of thyroid hormones during the treatment period, correlation coefficients have been calculated from the end of treatment to the end of the experiment.

\section{Results}

\section{Body and testicular growth}

Average daily feed intake $\mathrm{kg}^{-1}$ body weight and average daily gain were similar between groups and within the acceptable range for rapidly growing ram lambs (National Research Council, 1985). Average rectal temperatures of the lambs in both groups were similar throughout the experiment. Hematocrit measurements were similar in the two groups on each sampling day, indicating that there were no deteriorating effects due to frequent sampling.

The initial mean scrotal circumference of the control and $\mathrm{PTU}+\mathrm{H}$ groups were identical $(12.5 \pm 0.3 \mathrm{~cm})$ and remained similar until 21 weeks of age. From week 21 to week 26, testes of PTU+H lambs tended to grow faster than those of control lambs but the difference was not significant until week 26 through to the end of experiment, when scrotal circumference of $\mathrm{PTU}+\mathrm{H}$ lambs was greater than that of controls $(P<0.05 ;$ Fig. 1). At the end of the experiment, average scrotal circumference was $37.5 \pm 2.7$ and $42.4 \times 1.9 \mathrm{~cm}$ for control and $\mathrm{PTU}+\mathrm{H}$ groups, respectively. At 31 weeks of age, scrotal circumference reached a plateau in both groups. The average final testicular mass of the two groups were different at 


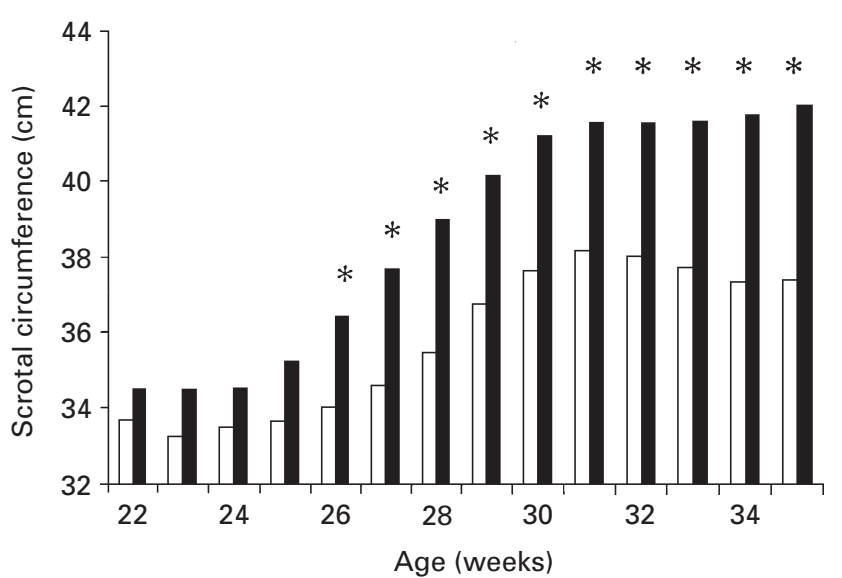

Fig. 1. Scrotal circumference of lambs treated with 6-propyl 2thiouracil orally and thyroxine and tri-iodothyronine s.c. $(\mathrm{PTU}+\mathrm{H}$; 口) and of control lambs ( $\square$ ) from 22 to 36 weeks of age. Asterisks indicate significant differences between the two groups $(P<0.05)$. Treatment started at week 6 and ended at week 12 of age. The SEM for each individual data point has been omitted for clarity. The range of SEMS was 1.00-1.82 and the overall SD of the means was \pm 4.0 .

$513.3 \pm 40.1$ and $674.5 \pm 33.7 \mathrm{~g}$ for control and PTU $+\mathrm{H}$ groups, respectively $(P<0.05)$. There was no within group difference between right and left testicular mass.

\section{Semen quality}

Semen was collected between 17 and 36 weeks of age. In the final ejaculation, semen volume was similar in the two groups $(1.05 \pm 0.09 \mathrm{ml}$ for control versus $1.2 \pm 0.09 \mathrm{ml}$ for $\mathrm{PTU}+\mathrm{H}$ lambs; $P>0.1)$ whereas sperm cell concentration was different $\left(2.07 \times 10^{9} \pm 0.06\right.$ spermatozoa $\mathrm{ml}^{-1}$ for control versus $2.54 \times 10^{9} \pm 0.09$ spermatozoa $\mathrm{ml}^{-1}$ for PTU+H lambs; $P<0.05)$. In the control group, viable sperm cells were first found at 20 weeks of age in one lamb and at 24 weeks of age in the second lamb. The third and fourth control lambs showed motile spermatozoa at 25 and 30 weeks of age, respectively. In the PTU $+\mathrm{H}$ group, the first and second lambs had viable spermatozoa at 18 weeks of age and the third and fourth lambs had viable spermatozoa at 19 weeks of age.

\section{Histology of the testis}

At 36 weeks of age, testicular development was greater in the PTU+H lambs and therefore more sperm cells were present in the lumen of seminiferous tubules. Although there were fewer seminiferous tubules in PTU $+\mathrm{H}(20 \pm 0.5)$ than in control lambs $(25 \pm 0.6 ; P<0.05)$, the diameter of the seminiferous tubules was greater in $\mathrm{PTU}+\mathrm{H}$ $(250-350 \mu \mathrm{m})$ than in control lambs $(200-300 \mu \mathrm{m} ; P<0.05)$. The diameter of the lumen was similar in both groups $(150 \pm 7.9)$. The number of layers of cells in the seminiferous tubules of the two groups was variable $(6 \pm 0.9$ layers of cells).

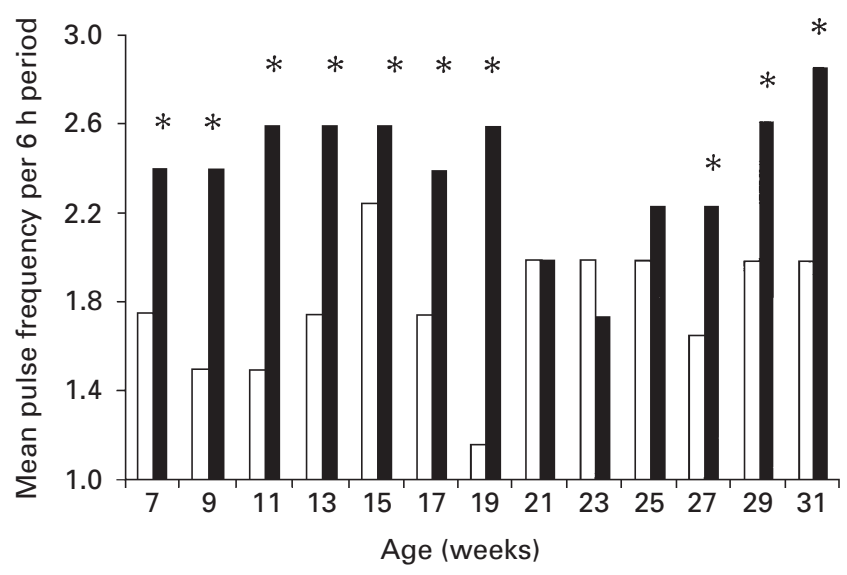

Fig. 2. Testosterone pulse frequencies per $6 \mathrm{~h}$ period during the experiment in lambs treated with 6-propyl 2-thiouracil orally and thyroxine and tri-iodothyronine s.c. $(\mathrm{PTU}+\mathrm{H} ; \mathbf{\square})$ and in control lambs ( $\square$ ). The average pulse frequency was higher in the PTU+H than in the control lambs. Asterisks indicate significant differences between the two groups $(P<0.01)$. Treatment started at week 6 and ended at week 12 of age. The SEM for each individual data point has been omitted for clarity. The range of SEMS was $0.13-0.38$ and the overall SD of the means was \pm 0.80 .

\section{Testosterone concentration and pulse frequency}

Average concentration of testosterone was similar in both groups throughout the experiment. There was a positive correlation between testosterone concentration and age of the lambs $(r=+0.74$ and +0.87 for control and PTU $+\mathrm{H}$ groups, respectively) indicating an effect of age on the testosterone concentration. The average number of testosterone pulses per $6 \mathrm{~h}$ sampling period was greater in $\mathrm{PTU}+\mathrm{H}$ than in control lambs by 1 week from induction of hyperthyroidism through until 4 weeks after ending treatment, and then again from 25 to 31 weeks of age $(P<0.01$; Fig. 2$)$. There were positive correlations between serum testosterone concentrations and testosterone pulse frequencies $(r=+0.68$ and +0.34 in control and PTU $+\mathrm{H}$ lambs, respectively).

\section{FSH concentration}

FSH concentration in the two groups was different from 6 to 9 weeks of age only $(P<0.05 ;$ Fig. 3$)$. The pattern of the FSH profile was the same in both groups and there was a positive correlation between $\mathrm{FSH}$ and age of the lambs in both groups $(r=+0.77$ and +0.81 for PTU $+\mathrm{H}$ and control lambs, respectively). Likewise, there was a positive correlation between FSH and testosterone concentration in both groups $(r=+0.55$ and +0.47 for control and PTU $+\mathrm{H}$ lambs, respectively). The correlation coefficients for FSH and scrotal circumference were +0.74 in the PTU $+\mathrm{H}$ and +0.72 in the control lambs.

\section{Insulin-like growth factor I concentration}

In PTU+H lambs, IGF-I concentrations were lower than 


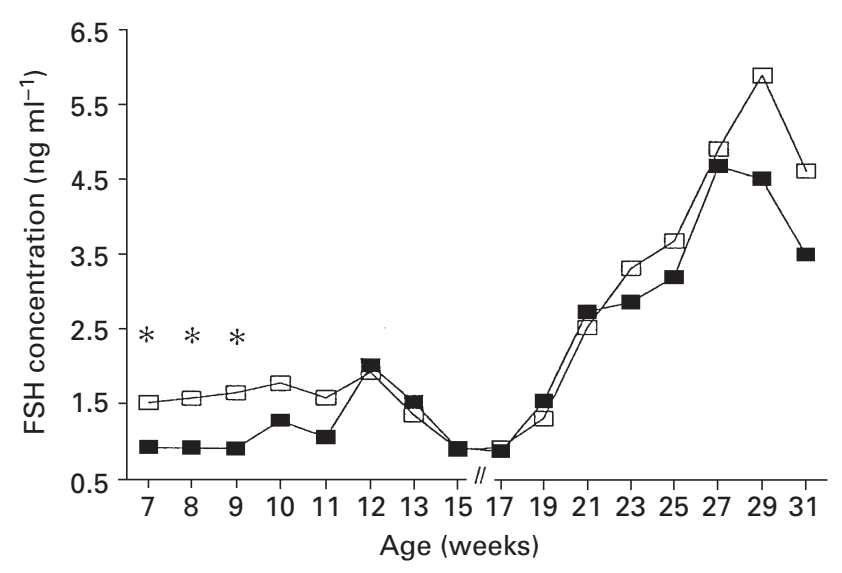

Fig. 3. Serum FSH concentrations in lambs treated with 6-propyl 2thiouracil orally and thyroxine and tri-iodothyronine s.c. (PTU $+\mathrm{H}$; 口) and in control lambs ( $\square$ ). FSH was lower at weeks 7, 8 and 9 in the $\mathrm{PTU}+\mathrm{H}$ than in the control lambs. Asterisks indicate significant differences between the two groups $(P<0.05)$. Treatment started at week 6 and ended at week 12 of age. The SEM for each individual data point has been omitted for clarity. The range of SEMs for weeks $7-13$ was $0.14-0.42$ and, for weeks $15-31$ was $0.10-0.82$. Overall SD of the means was \pm 0.70 and \pm 1.31 for weeks $7-13$ and 15-31, respectively.

those in controls at weeks 10, 11, 12 and 13 of age $(P<0.05)$ but were similar at other ages. The average IGF-I concentrations at week 11 were $412.5 \pm 19$ and $930 \pm 55 \mathrm{ng} \mathrm{ml}^{-1}$ for $\mathrm{PTU}+\mathrm{H}$ and control lambs, respectively. There was an effect of age on the IGF-I concentrations in both groups $(P<0.05)$. In the control group, the increase in the IGF-I concentration was biphasic. IGF-I increased from 7 to 15 weeks of age and then decreased until week 27 and increased again at 27 to 34 weeks of age $(P<0.05)$. In the PTU $+\mathrm{H}$ lambs, an increase in IGF-I concentrations started at weeks $8-10$ and then declined from week 10 to week 12 . After week 13, the IGF-I pattern was similar between the groups (Fig. 4) and from week 13 to the end of the experiment, there was a positive correlation between IGF-I, $\mathrm{T}_{3}$ and $\mathrm{T}_{4}(r=+0.48$ versus 0.79 for $\mathrm{T}_{3}$ and +0.79 versus +0.93 for $\mathrm{T}_{4}$ in the $\mathrm{PTU}+\mathrm{H}$ and control groups, respectively).

\section{Concentrations and ratio of $T_{4}$ and $T_{3}$}

In the PTU+H group, serum $\mathrm{T}_{4}$ and $\mathrm{T}_{3}$ concentrations were higher during the treatment period $(P<0.01)$ whereas their concentrations were similar thereafter. At week 6 (before treatment), concentrations of $\mathrm{T}_{4}$ and $\mathrm{T}_{3}$ were similar between the two groups; $\mathrm{T}_{4}$ concentrations were $5.8 \pm 0.2$ versus $5.8 \pm 0.3 \mu \mathrm{g} \mathrm{dl}^{-1}$ for control and PTU $+\mathrm{H}$ lambs, respectively, and $\mathrm{T}_{3}$ concentrations were $126.6 \pm 5.2$ and $105.6 \pm 5.5 \mathrm{ng} \mathrm{dl}^{-1}$ for control and PTU $+\mathrm{H}$ lambs, respectively. At week 10, mean $\mathrm{T}_{4}$ concentration reached a maximum value at $13.2 \pm 0.4 \mu \mathrm{g} \mathrm{dl}^{-1}$ in $\mathrm{PTU}+\mathrm{H}$ lambs while, in controls, it was $5.14 \pm 0.5 \mu \mathrm{g} \mathrm{dl}{ }^{-1}$ (Fig. 5). At week 9, in the PTU $+\mathrm{H}$ group, $\mathrm{T}_{3}$ concentration reached a

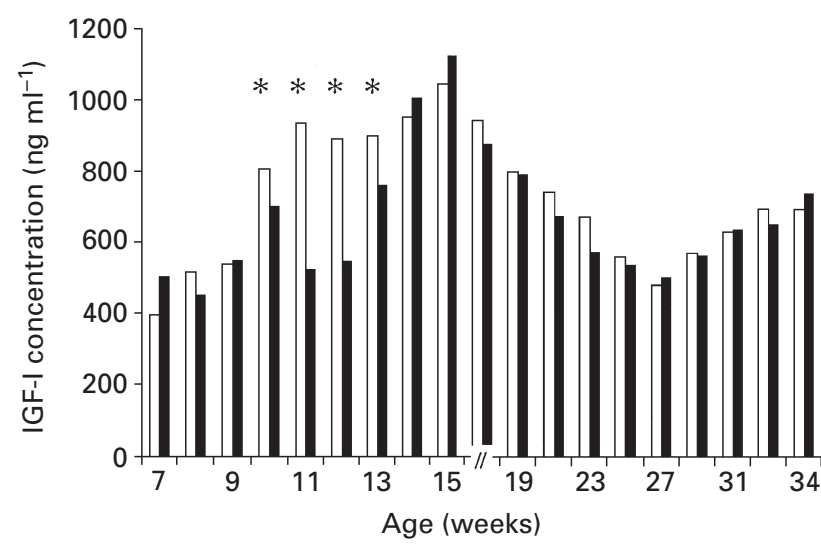

Fig. 4. Serum concentrations of insulin-like growth factor I (IGF-I) in lambs treated with 6-propyl 2-thiouracil orally and thyroxine and tri-iodothyronine s.c. (PTU+H; $\mathbf{\square}$ ) and in control lambs $(\square)$. Average IGF-I concentrations were lower in the PTU $+\mathrm{H}$ than in the control lambs at 10, 11, 12 and 13 weeks of age. Asterisks indicate significant differences between the two groups $(P<0.05)$. Treatment started at week 6 and ended at week 12 of age. The SEM for each individual data point has been omitted for clarity. The range of SEMS was 15.90-53.15 and the overall SD of the means was \pm 75.98 .

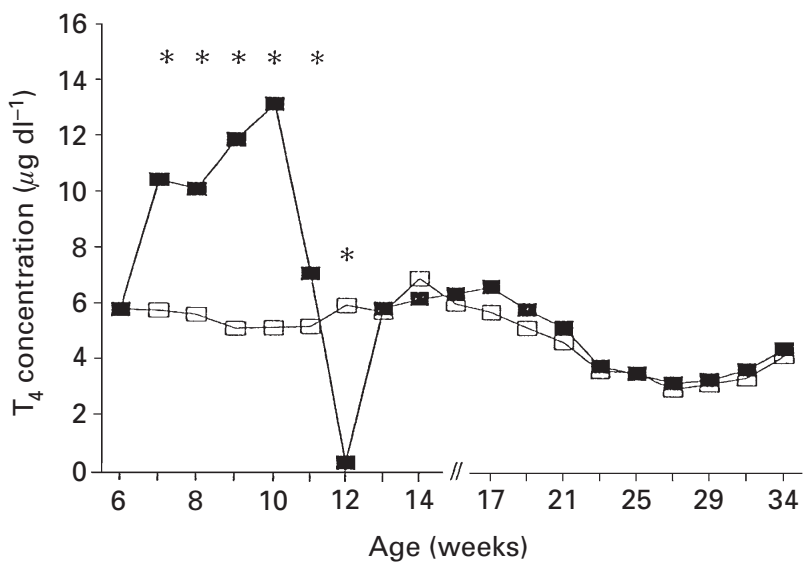

Fig. 5. Serum thyroxine $\left(T_{4}\right)$ concentrations in lambs treated with 6propyl 2-thiouracil orally and thyroxine and tri-iodothyronine s.c. $(\mathrm{PTU}+\mathrm{H} ; \mathbf{\square})$ and in control lambs $(\square)$. During weeks $7-11, \mathrm{~T}_{4}$ concentrations were higher in the $\mathrm{PTU}+\mathrm{H}$ than in the control lambs $(P<0.01)$, but were lower in the PTU+H lambs at week 12. Asterisks indicate significant differences between the two groups $(P<0.01)$. Treatment started at week 6 and ended at week 12 of age. The SEM for each individual data point has been omitted for clarity. The range of SEMS was $0.07-0.57$ and the overall SD of the means was \pm 0.97 .

maximum value at $544 \pm 47.0$ versus $157.3 \pm 26 \mathrm{ng} \mathrm{dl}^{-1}$ in the control group (Fig. 6). The ratio of $\mathrm{T}_{4}: \mathrm{T}_{3}$ during the treatment period was $38.9 \pm 2.5$ in control and $32.9 \pm 6.6$ in PTU $+\mathrm{H}$ lambs, whereas after treatment until the end of experiment it was $43.9 \pm 2.4$ versus $46.7 \pm 2.6$ for control and $\mathrm{PTU}+\mathrm{H}$ lambs, respectively. There was a negative 


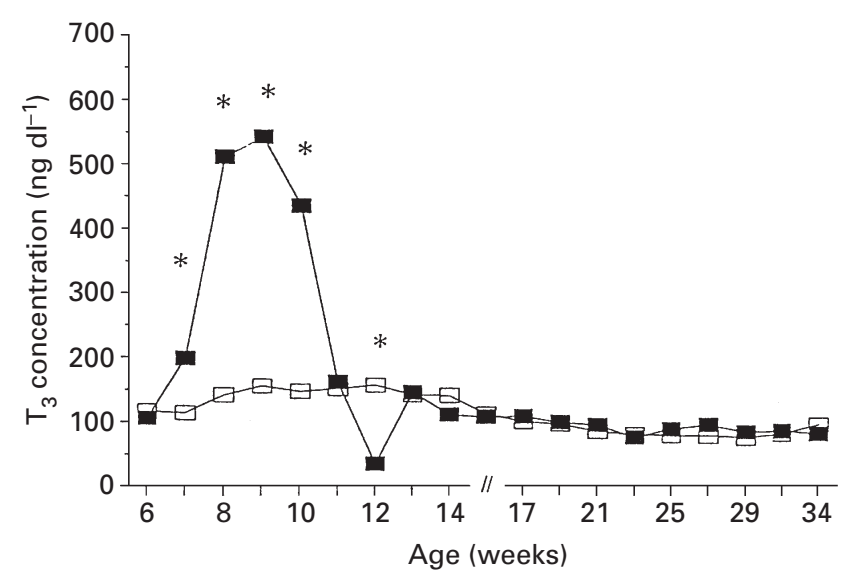

Fig. 6. Serum tri-iodothyronine $\left(T_{3}\right)$ concentrations in lambs treated with 6-propyl 2-thiouracil orally and thyroxine and triiodothyronine s.c. (PTU+H; $\mathbf{\square})$ and in control lambs ( $\square)$. During weeks $7-10, \mathrm{~T}_{3}$ concentrations were higher in the $\mathrm{PTU}+\mathrm{H}$ than in the control lambs $(P<0.01)$. At week 12 , the concentration of $\mathrm{T}_{3}$ decreased in the PTU+H lambs to nearly zero. Asterisks indicate significant differences between the two groups $(P<0.01)$. Treatment started at week 6 and ended at week 12 of age. The SEM for each individual data point has been omitted for clarity. The range of SEMS for weeks 6-13 was 2.75-39.66 and the overall SD was \pm 38.94 .

correlation between the $\mathrm{T}_{3}$ concentration and age of the lambs ( $r=-0.58$ for PTU $+\mathrm{H}$ and -0.8 for control lambs). The Pearson product-moments for $\mathrm{T}_{4}$ and age of the lambs were -0.65 and -0.78 for $\mathrm{PTU}+\mathrm{H}$ and control lambs, respectively, indicating the effect of age on the concentration of thyroid hormones. After administration of the hormones ended at 12 weeks of age, the serum concentration of the hormones in the $\mathrm{PTU}+\mathrm{H}$ group decreased markedly (to $0.32 \pm 0.15 \mu \mathrm{g} \mathrm{dl}^{-1}$ for $\mathrm{T}_{4}$ and $38.1 \pm 4.9 \mathrm{ng} \mathrm{dl}^{-1}$ for $\mathrm{T}_{3}$ ). The concentrations of both $\mathrm{T}_{4}$ and $T_{3}$ increased and were comparable to controls within the next 2 weeks.

\section{Discussion}

In other studies, administration of $\mathrm{T}_{4}$ to adult sheep at the rate of $13.15 \mu \mathrm{g} \mathrm{kg}^{-1}$ body weight per day did not produce catabolic effects of thyrotoxicosis, although live weight was slightly reduced (Godden and Weekes, 1984). Moreover, $\mathrm{T}_{3}$ injection into young lambs at the rate of $5 \mu \mathrm{g} \mathrm{kg}^{-1}$ body weight per day did not result in serum $\mathrm{T}_{3}$ concentrations within the toxic range (Lynch et al., 1983). Likewise, in the present study, administration of 8 and $16 \mu \mathrm{g} \mathrm{kg}^{-1}$ body weight per day of $T_{3}$ and $T_{4}$, respectively, did not result in symptoms of thyrotoxicosis. Thyroid hormones in treated lambs returned to concentrations similar to those in controls within 2 weeks of stopping treatment. The reduced $\mathrm{T}_{4}$ and $\mathrm{T}_{3}$ concentrations in the first week after treatment were likely due to residual depressor effects of the treatment on thyroid function, TSH and TRH release (Hadley, 1992). The ratio of $T_{4}: T_{3}$ was similar during and after treatment, implying that the amounts administered corresponded to the normal physiological ratio.

In spite of the initial lower relative growth, the transient hyperthyroidism did advance testicular function and onset of puberty in treated lambs. This finding contrasts with results from rats in which hyperthyroidism reduced final testicular size (van Haaster et al., 1993), and hypothyroidism increased testicular size at puberty (van Haaster et al., 1992). Hypothyroidism leading to increased testicular size at puberty was determined to be the result of hyperplasia and hypertrophy of Sertoli and Leydig cells (Cooke et al., 1992). Cooke et al. (1994a) noted that $T_{3}$ directly inhibited mitogenesis of cultured neonatal rat Sertoli cells. Therefore, smaller testes with fewer more differentiated Sertoli cells might have been expected in $\mathrm{PTU}+\mathrm{H}$ lambs compared with controls. However, the converse occurred.

Transiently hyperthyroid lambs produced more viable sperm cells earlier than did euthyroid lambs, indicating that the Sertoli cells of the PTU+H lambs were at more advanced stages of maturation and able to support and nourish a greater number of sperm cells. The increase in testicular size of PTU $+\mathrm{H}$ lambs may be due to hypertrophy of Sertoli cells and hyperplasia of the germ cells. An eightfold increase in Sertoli cell protoplasm normally occurs during the peripubertal period in lambs (Monet-Kuntz et al., 1988). Mature Sertoli cells produce androgen-binding protein (ABP), which binds to testosterone (Martin et al., 1991), thereby increasing testosterone concentration in the seminiferous tubules. The maintenance of high intratesticular testosterone concentrations enhances spermatogenesis and the nourishment of the developing germ cells (Mita et al., 1982). Therefore, it appears that excess thyroid hormones during early development enhance maturation and growth of the testes and advance the chronology of testicular growth in ram lambs. However, the mechanisms remain to be clarified.

The relationship between hyperthyroidism and testosterone concentration has not been defined. The higher testosterone pulse frequency associated with advancing puberty (Renaville et al., 1993) in the PTU+H lambs was more likely due to increased pulsatility of $\mathrm{GnRH}$ and LH (Sanford et al., 1978) than to the changes in the FSH concentration. Throughout the sampling periods, FSH concentration was not higher in the PTU+H lambs than it was in controls. Reductions in the concentration of $\mathrm{FSH}$ in the hyperthyroid lambs were transient, whereas reduction of FSH in hyperthyroid (van Haaster et al., 1993) and hypothyroid rats (Kirby et al., 1992) was permanent. In cultured neonatal rat Sertoli cells, $\mathrm{T}_{3}$ alone or in combination with $\mathrm{FSH}$ stimulated production of inhibin- $\beta_{\mathrm{b}}$ mRNA (Cooke et al., 1994a). It is conceivable that high concentrations of thyroid hormones in the PTU+H lambs increased inhibin production by the Sertoli cells, thereby causing a reduction in $\mathrm{FSH}$ concentration. There was no apparent deleterious effect on testes development or spermatogenesis. 
The lower IGF-I concentration in the hyperthyroid lambs during treatment is consistent with the results of Elsasser et al. (1991) in steers. At physiological concentrations, thyroid hormones stimulate pituitary $\mathrm{GH}$ production which, in turn, stimulates IGF-I production in the liver and other tissues (McGuire et al., 1992). Alteration of thyroid function can affect pituitary GH mRNA production (Samuels et al., 1989) and hepatic IGF-I production. Although transiently lower peripheral IGF-I concentrations may reflect central suppression of $\mathrm{GH}$, testicular concentrations of IGF-I may have been quite different. Thyroid hormones control production and secretion of IGF-1 in Sertoli cells (Smith et al., 1987). Therefore, the transient increase in thyroid hormone concentrations may have promoted Sertoli cell maturation and spermatogenesis through increased IGF-I concentration in the microenvironment of the seminiferous tubules.

This is the first report of juvenile hyperthyroidism in sheep. The present results show that transient hyperthyroidism enhanced the sequence of events leading to the onset of puberty in hyperthyroid lambs, and enhanced testicular size and sperm output. These findings are in contrast with the situation in rats and may reflect developmental differences between the species. Maximum proliferation of rat Sertoli cells occurs perinatally coincident with the onset of neonatal thyroid function (Jannini et al., 1990). In lambs, thyroid activity begins in utero and maximal Sertoli cell proliferation occurs early in post-natal life (Gordos and Berndston, 1993). However, even though the time window of effectiveness and rate of proliferation may differ between lambs and rats (Cook et al., 1994b), it remains unclear why the response to thyroid hormones should be opposite. A number of questions remain unanswered. The reason for the higher testosterone pulse frequency, increased testicular size and function in the $\mathrm{PTU}+\mathrm{H}$ lambs compared with controls remains to be determined. However, the present study provides some insight into the complexity of neonatal gonad development and the involvement of thyroid hormones in this process. Even short-term hyperthyroidism can have provocative influences on gonad development and function in ram lambs.

The authors thank F. Araneda for technical assistance, R. Stuski for assistance with animal handling and management, L. Onischuk, N. Funk and K. Orzechowski for blood sampling. The statistical advice of G. Crow and L. Onischuk is appreciated. The financial support provided by the Ministry of Culture and Higher Education of Iran and the University of Manitoba are gratefully acknowledged.

\section{References}

Breier BH, Bass JJ, Butler JH and Gluckman PD (1986) The somatotrophic axis in young steers: influence of nutritional status on pulsatile release of growth hormone and circulating concentrations of insulin-like growth factor I Journal of Endocrinology 111 209-215

Brzezinska-Slebodzinska E and Krysin E (1990) Investigation of thyroxine monodeiodinase activity in the liver, kidney and brown adipose tissue of foetal and neonatal rabbit Journal of Developmental Physiology 13 309-314
CCAC (1993) Canadian Council on Animal Care Guide to the Care and Use of Experimental Animals 2nd Edn. Bradda Printing Services Inc., Ottawa, Ontario

Cooke PS and Meisami E (1991) Early hypothyroidism in rats causes increased adult testis and reproductive organ size but does not change testosterone levels Endocrinology 129 237-243

Cooke PS, Porcelli J and Hess RA (1992) Induction of increased testis growth and sperm production in adult rats by neonatal administration of the goitrogen propylthioracil (PTU): the critical period Biology of Reproduction 46 146-154

Cooke PS, Zhao YD and Bunick D (1994a) Tri-iodothyronine inhibits proliferation and stimulates differentiation of cultured neonatal Sertoli cells: possible mechanism for increased adult testis weight and sperm production induced by neonatal goitrogen treatment Biology of Reproduction $\mathbf{5 1}$ 1000-1005

Cooke PS, Hess RA and Kirby JD (1994b) A model system for increasing testis size and sperm production: potential application to animal science Journal of Animal Science 72 Supplement 3 43-54

Daughaday WH and Rotwein P (1989) Insulin-like growth factors I and II. Peptide, messenger ribonucleic acid and gene structures, serum, and tissue concentrations Endocrinology Review 10 68-91

Dubois JD and Dussault JH (1977) Ontogenesis of thyroid function in the neonatal rat. Thyroxine $\left(\mathrm{T}_{4}\right)$ and Tri-iodothyronine $\left(\mathrm{T}_{3}\right)$ production rate Endocrinology 101 435-441

Elsasser TH, Ramsey TS and Kahl S (1991) Relationships between the thyroid and somatotropic axes in steers II: effects of thyroid status on plasma concentrations of insulin like growth factor I (IGF-I) and the IGF-I response to growth hormone Domestic Animal Endocrinology 10 71-85

Evans ACO, Currie WD and Rawlings NC (1992) Effects of naloxone on circulating gonadotrophin concentrations in prepubertal heifers Journal of Reproduction and Fertility 96 847-855

Francis GL, Owens PC, McNeil KA, Wallace JC and Ballard FJ (1989) Purification, amino acid sequences and assay crossreactivities of porcine insulin-like growth factor I and II Journal of Endocrinology 122 681-687

Godden PMM and Weekes TEC (1984) Influence of chronic thyroxine treatment on plasma hormone and metabolite concentrations and on responses to insulin, glucagon and thryotropin releasing hormone in adult sheep Hormone Metabolism Research 16 354-358

Gondos B and Berndston WE (1993) Postnatal and pubertal development. In The Sertoli Cell pp 115-153 Eds LD Russell and MD Griswold. Cache River Press, Clearwater, FL

Hadley ME (1992) Endocrinology 3rd Edn pp 334-335 Prentice Hall, Englewood Cliffs, NJ

Hess RA, Cooke PS, Bunick D and Kirby JD (1993) Adult testicular enlargement induced by neonatal hypothyroidism is accompanied by increased Sertoli and germ cell numbers Endocrinology 132 2607-2613

Jannini EA, Olivieri M, Francavilla S, Gulino A, Ziparo E and D'Armiento M (1990) Ontogenesis of the nuclear 3,5,3' -tri-iodothyronine receptor in the rat testis Endocrinology 126 2521-2526

Joyce KL, Porcelli J and Cooke PS (1993) Neonatal goitrogen treatment increases adult testis size and sperm production in the mouse Journal of Andrology 14 448-455

Kirby JD, Jetton AE, Cooke PS, Hess RA, Bunick D, Ackland JF, Turek FW and Schwartz NB (1992) Developmental hormonal profiles accompanying the neonatal hypothyroidism-induced increase in adult testicular size and sperm production in the rat Endocrinology 131 559-565

Kirby JD, Cooke PS, Arambepola N, Bunick D, Hess RA and Turek FW (1993) Neonatal hypothyroidism increased adult testis size and sperm production in the hamster (Mesocricetus auratus) Program of the 12th North American Testis Workshop, Tampa, FL P51 (Abstract)

Lynch MA, Andrews JF and Moore RE (1983) Low doses of $\mathrm{T}_{3}$ induce a rapid metabolic response in young lambs Hormone Metabolism Research 17 63-66

McGuire MA, Vicini JL, Bauman DE and Veenhuizen JJ (1992) Insulin-like growth factors and binding proteins in ruminants and their nutritional regulation Journal of Animal Science 70 2901-2910 
Martin TL, Williams GL, Lunstra DD and Ireland JJ (1991) Immunoneutralization of inhibin modifies hormone secretion and sperm production in bulls Biology of Reproduction 45 73-77

Meisami E, Najafi A and Timiras PS (1994) Enhancement of seminiferous tubular growth and spermatogenesis in testes of rats recovering from early hypothyroidism: a quantitative study Cell and Tissue Research 275 503-511

Milter KP and Albyl AT (1985) Evaluation of RIA kits for the measurement of thyroid hormones in sheep and cattle sera New Zealand Veterinary Journal 33 116-117

Mita M, Price JM and Hall PF (1982) Stimulation by follicle-stimulating hormone of synthesis of lactate by Sertoli cells from rat testis Endocrinology 110 1535-1541

Monet-kuntz C, Hochereau-de Reviers MT, Pesselet C, Perreau C, Fontaines L and Schanbacher BD (1988) Endocrine parameters, hormone receptors and functions of the testicular interstitium and seminiferous epithelium in estradiol-immunized Ile-de-France rams Journal of Andrology 9 278-283

National Research Council (1985) Nutrient Requirements of Sheep 6th Edn pp 46-47 National Academy Press, Washington DC

Oppenheimer JH, Schwartz HL and Suks MI (1974) Tissue differences in the concentration of triiodothyronine nuclear binding sites in the rat: liver, kidney, pituitary, heart, brain, spleen and testis Endocrinology 95 897-903

Orth JM, Gunsalus GL and Lamperti AA (1988) Evidence from Sertoli celldepleted rats indicates that spermatid number in adults depends on numbers of Sertoli cells produced during perinatal development Endocrinology 122 787-794

Palmero S, Maggiani S and Fugassa E (1988) Nuclear tri-iodothyronine receptors in rat Sertoli cells Molecular and Cellular Endocrinology 58 253-256

Palmero S, Benahmed M, Morera AM, Tricchi P and Fugassa E (1992) Identification of nuclear tri-iodothyronine receptors in Sertoli cells from immature piglet testes Journal of Molecular Endocrinology 9 55-59

Renaville R, Devolder A, Massart S, Sneyers M, Burny A and Porteltelle D (1987) Changes in the hypophysial-gonadal axis during the onset of puberty in young bulls Journal of Reproduction and Fertility 99 443-449

Russell S, Bartke A and Goh JC (1989) Postnatal development of the Sertoli cell barrier, tubular lumen, and cytoskeleton of Sertoli and myoid cells in the rat, and their relationship to tubular fluid secretion and flow American Journal of Anatomy 184 179-189
Sakurai H, Adams BM, Oberbauer AM and Adams TE (1993) Gonadotrope responsiveness in orchedectomized sheep Biology of Reproduction $\mathbf{4 8}$ 683-691

Samuels MH, Sierman ME, Wang C and Ridgway EC (1989) The effect of altered thyroid status on pituitary hormone messenger ribonucleic acid concentrations in the rat Endocrinology 124 2277-2282

Sanford LM, Winter JSD, Palmer WM and Howland BE (1974) The profile of $\mathrm{LH}$ and testosterone secretion in the ram Endocrinology 95 627-631

Sanford SM, Beaton DB, Howland BE and Palmer WM (1978) Photoperiodinduced changes in $\mathrm{LH}, \mathrm{FSH}$, prolactin and testosterone secretion in the ram Canadian Journal of Animal Science 58 123-128

Smith EP, Svoboda ME, Van Wyk JJ, Kiezenbaum AL and Tress LU (1987) Partial characterization of a somatomedin-like peptide from the medium of cultured rat Sertoli cells Endocrinology 120 186-193

Steel RGD and Torrie JH (1960) Principles and Procedures of Statistics: a Biomedical Approach p 106 McGraw-Hill Co. Inc., New York, Toronto, London

Van Haaster LH, De Jong FH, Docter R and De Rooij DG (1992) The effect of hypothyroidism on Sertoli cell proliferation and differentiation and hormone levels during testicular development in the rat Endocrinology 131 1574-1576

Van Haaster LH, De Jong FH, Docter R and De Rooij DG (1993) High neonatal triiodothyronine levels reduce the period of Sertoli cell proliferation and accelerate tubular lumen formation in the rat testis, and increase serum inhibin levels Endocrinology 133 755-760

Veldhuis JD, Evans WS, Rogol AD, Drake CR, Thorner MO, Merriam GR and Johnson ML (1984) Intensified rates of venous sampling unmask the presence of spontaneous, high frequency pulsation of luteinizing hormone in man Journal of Clinical Endocrinology and Metabolism 59 96-102

Wilson PR and Lapwood KR (1979) Studies of reproductive development in Romney rams I. Basal levels and plasma profiles of $\mathrm{LH}$, testosterone and prolactin Biology of Reproduction 20 965-970

Wrutniak C, Cabello G and Bosc M (1985) Plasma free and tota iodothyronine levels in hypophysectomized and intact lamb fetuses during the last third of gestation Acta Endocrinologica $110388-394$

Resubmitted manuscript received 4 January 2000.

First decision 26 January 2000.

Revised manuscript received 27 October 2000.

Accepted 15 November 2000. 